\title{
Valorization of Agro-Industrial By-products: Use of Rice Husk as a Source of Microorganisms to Denitrification of Water
}

Jair Juarez João (Corresponding author), José Luiz Vieira, Marcos Henrique Luciano Silveira, Cristiane Silvano Wensing. E-mail: jair.joao@unisul.br; jairjoao05@gmail.com

Technological Center, University of Southern Santa Catarina, UNISUL, Av Acácio Moreira 787, Dehon, Tubarão, 88704-900, Santa Catarina, Brazil

Paulo Cesar de Jesus, Endler Marcel Borges

Departamento de Química, Fundação Universidade Regional de Blumenau, FURB, Campus 1, Rua Antônio da Veiga, 140, Victor Konder, 89012-900 Blumenau-SC, Brasil.

Received: August 5, 2020

doi:10.5296/jas.v8i4.17624
Accepted: August 25, 2020

Published: Sep. 1, 2020

URL: https://doi.org/10.5296/jas.v8i4.17624

\begin{abstract}
Rice husk, which is an agricultural waste, provides a feasible alternative for the growth and propagation of denitrifying microorganisms. Nitrate and nitrite were removed using Immobilized Microorganisms (MO IM) or Microorganisms in Solution (MOso). Microorganisms present in the rice husk biomass responsible for denitrification were identified as Pseudomonas, and other microorganisms have also been identified, as Oerskovia spp. Enterococcus sp. Bacillus mycoides and Escherichia coli. The influence of $\mathrm{pH}$, temperature, $\mathrm{C} / \mathrm{N}$ ratio and carbon source on biological denitrification were investigated. MOIM and MOso consortium had optimal denitrifying performance at $25-30{ }^{\circ} \mathrm{C}$ and in $\mathrm{pH}$ 7-8. MOso has average denitrification efficiency larger than MO IM. The MO IM denitrification efficiency was more sensitive to $\mathrm{pH}$ changes than the MOso. Ethanol and sodium acetate were carbon sources for the denitrifying process. The efficiency of nitrate and nitrite removal using MOso and ethanol or acetate with 1:1, 1:2, 1:3 and 1:4 C/N ratios were equivalents and above $97.00 \%$. The denitrifying process presented was robust and it presented nitrate removal close to $100 \%$ during 10 cycles.
\end{abstract}

Keywords: wastewater treatment, water, pollution, denitrification, rice husk 


\section{Introduction}

Safe water is crucial for humans, plants, and animals (Abu Hasan et al., 2020). Nowadays, water quality preservation is an important environmental issue where agricultural activities, industrial and domestic effluents are the main contamination sources of water (Júnior et al., 2007; Shamsollahi \& Partovinia, 2019).

In many parts of the world, groundwater and superficial waters are widely used as drinking water. Over the decades, human activity increased nitrate $\left(\mathrm{NO}_{3}{ }^{-}\right)$concentration in groundwater and superficial waters due to human activity (Hou et al., 2019; Wan et al., 2015). Several factors contribute to this problem, such as: industrial effluents, final disposal of domestic sewage and the indiscriminate use of fertilizers and pesticides in agriculture (Liu et al., 2020; Zhang et al., 2016).

At high concentrations, nitrate cause eutrophication and toxic algal blooms in receiving waters. It is identified as one of the hazardous contaminants in drinking water, it can cause blue baby syndrome and nitrate reduction to nitrite induce the formation of carcinogenic nitrosamines (Fan \& Steinberg, 1996).

The US Environmental Protection Agency set the nitrate maximum admissible in drinking water as $10 \mathrm{mg} \mathrm{L}^{-1}$ as nitrate-nitrogen $\left({\mathrm{N}-\mathrm{NO}_{3}}^{-}\right)$and the World Health Organization set a limit of $50 \mathrm{mg} \mathrm{L}^{-1}$ as nitrate ( He et al., 2016).

Nitrite and nitrate have high solubility in water and, its removal via precipitation is impractical. Thus, nitrate removal using conventional water treatment technologies is a challenge ( Chen et al., 2019; Hou et al., 2019). Nitrate removal was carried out using several treatment, such as: adsorption, (Chuah et al., 2005) membrane separation (Pan et al., 2020) and electrochemical processes (Garcia-Segura et al., 2018). The main drawbacks of these processes were generation of undesirable by-products and its high cost. Thus, biological nitrate removal process is a promising alternative (Di Capua et al., 2019).

Biological nitrogen compounds removal $\left(\mathrm{NO}_{3}{ }^{-}, \mathrm{NO}_{2}{ }^{-}\right.$and $\left.\mathrm{NH}_{4}{ }^{+}\right)$is a selective method, but it is more cost-effective than traditional physicochemical methods (Liu et al., 2012). The heterotrophic biological denitrification process demands an incessant supply of external organic matter - such as methanol, ethanol or sodium acetate - which provides source for bacterial growth, as well as, generate energy for the conversion of nitrate into gaseous nitrogen, according to equation 1 ( He et al., 2018; Tian \& Yu, 2020).

$$
\mathrm{NO}_{3}{ }^{-} \rightarrow \mathrm{NO}_{2}{ }^{-} \rightarrow \mathrm{NO} \rightarrow \mathrm{N}_{2} \mathrm{O} \rightarrow \mathrm{N}_{2}
$$

Agro-industrial waste - such as sugarcane bagasse, wheat straw, corn stover and rice husk are used in biological denitrification processes, where it can promote reproduction many microorganisms and it is also a carbon source for the denitrifying process (Maheshwari et al., 2014).

Some authors (Della et al., 2001; Shamsollahi \& Partovinia, 2019) reviewed the pollutants removal by rice husk. They claimed, for example, that the rice husk is $20-25 \% \mathrm{w} / \mathrm{w}$ amount 
of the whole paddy produced (Della et al., 2001). This is an agricultural waste that is widely available, and it has been used as an adsorbent to remove heavy metals, organic pollutants, and dyes.

The main constituents of the rice husks were cellulose (34.61\% weight basis - wb), lignin (19.66\% wb), ash (16.82\% wb), hemicellulose (10.90\% wb), and protein (3.16\% wb) (João et al., 2020). Where, rice husk composition changes from one sample to another because soil, climate, and geographical location and cultivar differences (Shamsollahi \& Partovinia, 2019).

Few studies used husk as a source of denitrifying microorganisms. Thus, the efficiency of the denitrification process under various conditions with the participation of rice husk microorganisms was evaluated.

\section{Materials and Methods}

All chemical reagents such as, sodium hydroxide, sulfuric acid, sodium nitrate, sodium nitrite, used were analytical grade. Deionized water was obtained using a Millipore Milli-Q system. Solutions were prepared using deionized water,

\subsection{Rice Husk as Source of Microbiota}

The study was carried out using rice husk collected at an agricultural rice processing cooperative (COPAGRO), in the south of Santa Catarina, Brazil. The microorganisms used in this study were immobilized in rice husk biomass (МО IM) or suspended microorganisms in solution (MOso).

\subsection{Denitrification Using Microorganisms Immobilized on the Rice Husk and Suspended in Solution}

In a $500 \mathrm{~mL}$ Erlenmeyer, rice husk was weighed and homogenized using aqueous nitrate solution (35 mg L $\mathrm{m}^{-1} \mathrm{~N}^{-\mathrm{NO}_{3}}{ }^{-}$) resulting in $15 \%$ (w/v). The solution was kept under Dubnoff orbital agitation at $30^{\circ} \mathrm{C}$ for 72 hours. This last cycle was repeated twice in a row for the growth and proliferation of denitrifying microorganisms. Subsequently, rice husks with immobilized microorganisms were separated from the crude bacterial extract both fractions (MO ${ }_{\text {Iм }}$ and $\mathrm{MO}_{\text {so) }}$ ) are used for denitrification experiments.

Initially, nitrate removal experiments were carried out using $100 \mathrm{~mL}$ crude extract (MOso) and sodium nitrate in a of $35 \mathrm{mg} \mathrm{L}^{-1}$ concentration. Nitrate removal experiments using microorganisms MOІм were carried out using $100 \mathrm{~mL}$ of a $35 \mathrm{mgL}^{-1}$ sodium nitrate solution. Both experiments were carried out using a Dubnoff water bath, in a $250 \mathrm{~mL}$ Erlenmeyer, at $30{ }^{\circ} \mathrm{C}$ and $\mathrm{pH} \mathrm{7}$, under constant shaking at $30 \mathrm{rpm}$. The aliquots were collected at intervals of $6,12,18$, and 24 hours.

Posteriorly, the reactions were carried out under different conditions of nitrate concentration (35, 70, 105,140 and $\left.280 \mathrm{mg} \mathrm{L}^{-1} \mathrm{~N}-\mathrm{NO}_{3}{ }^{-}\right), \mathrm{pH}(5,6,7,8$ and 9), temperature $(15,25,30,40$ and $\left.500{ }^{\circ} \mathrm{C}\right)$ and $\mathrm{C} / \mathrm{N}$ Ratio $(1: 1,2: 1 ; 3: 1,4: 1$ and $5: 1)$. Ethanol or sodium acetate were used an external carbon source.

The control treatment was carried out in the absence of an external carbon source. All 
experiments were carried out in triplicate.

\subsection{Identification of the Presence of Denitrifying Microorganisms}

To generate the microorganisms, the rice husk biomass was washed with running water and mixed with aqueous nitrate solution $\left(35 \mathrm{mg} \mathrm{L}^{-1}{\mathrm{~N}-\mathrm{NO}_{3}}^{-}\right)$resulting in $15 \%(\mathrm{w} / \mathrm{v})$. After the complete removal of nitrate, the denitrified water was again contaminated with aqueous nitrate solution and a carbon source (C/N Ratio 1:1). After $72 \mathrm{~h}$ incubation, (shaking regime at water bath at $30{ }^{\circ} \mathrm{C}$ ), samples were centrifuged (6000 rpm for $8 \mathrm{~min}$ ) and bacterial pellet was collected. Thereafter, microorganisms were prior inoculated into $250 \mathrm{~mL}$ Erlenmeyer containing aqueous nitrate solution and carbon source for anaerobic conditions incubation. Last step was repeated three times in a row to produce microorganisms. Finally, microorganism samples were seed on Mueller-Hinton agar, where colonies growth, then, colonies were separated using successive sowing on Macconkey and Blood agar plates, to obtain pure cultures.

The colonies were morphologically characterized (color, shape, elevation), submitted to GRAM staining and biochemical tests (catalase and oxidase). The bacteria were identified at the UNISUL Biochemistry Laboratory (CENTEC), based on morphological and biochemical tests (João et al., 2020).

\subsection{Assessment of Operational Robustness}

Microorganism recycling experiments were carried out using MOso or MOІM. After complete denitrification, different amounts of denitrified water were withdraw, and the resulting volume, called crude extract, was filled to $100 \mathrm{~mL}$, with nitrate contaminated water (35 $\mathrm{mg} \mathrm{L}^{-1} \mathrm{~N}_{-} \mathrm{NO}_{3}{ }^{-}$) and a source of carbon added. Volumes crude extract used in the different biological denitrification cycles were 10, 20, 30, 40, 50 and $100 \mathrm{~mL}$.

\subsection{Determination of Nitrogen Containing Species}

Denitrification process was monitored by the analysis of nitrite and nitrate, by using methodologies $4500-\mathrm{NO}_{2}{ }^{-} \mathrm{B}$ and $4500-\mathrm{NO}_{3}{ }^{-} \mathrm{B}$, respectively. These methods followed the description on $22^{\text {th }}$ edition of the Standard Methods for the Examination of Water and Wastewater (APHA, 2012). Analyses were carried out by using a UV/VIS spectrophotometer PHARO 300 (Merck). Obtained results were used to express nitrogen content, either in the bases of nitrate $\left(\mathrm{N}^{-\mathrm{NO}_{3}}{ }^{-}\right)$or nitrite $\left(\mathrm{N}^{-\mathrm{NO}_{2}}{ }^{-}\right)$anions. The water $\mathrm{pH}$ was measured by a portable $\mathrm{pH}$ meter (Hanna).

\section{Results and Discussion}

Pseudomonas (GRAM negative), Oerskovia spp. (GRAM positive Bacilli), Enterococcus sp. (GRAM positive Cocci), Bacillus mycoide (GRAM positive Bacilli), and Escherichia coli (GRAM negative) are isolated from rice husk biomass. These bacteria form a biofilm in the growth medium and these biofilms are responsible for the process of biological denitrification of the water samples tested. Pseudomonas are the principal microorganism responsible for the denitrification process. These microorganisms were used either Immobilized in Rice Biomass (MO IM) or Suspended Microorganisms in Solution (MOso). There was no 


\section{Macrothink}

Journal of Agricultural Studies

ISSN 2166-0379

2020, Vol. 8, No. 4

denitrification using autoclaved rice husk, which means that selected MO were required for denitrification process.

The period of greatest removal of $\mathrm{N}$ was up to 6 hours of the experiment, in which $\mathrm{N}_{-} \mathrm{NO}_{3}{ }^{-}$ was reduced from 35 to $22.6 \mathrm{mg} \mathrm{L}^{-1}$, and $\mathrm{N}^{-N_{2}}{ }_{2}^{-}$from 35 to $19.6 \mathrm{mg} \mathrm{L}^{-1}$, representing removals close to $40 \%$ (Figure 1 ).

At the beginning of the test, there were larger nutrients and $\mathrm{N}$ concentrations available to microorganisms than at any other time, and these larger concentrations induce the microbial activity (Bankston et al., 2020). Therefore, the rate of removal decreases progressively until reaching the equilibrium state ( $99 \%$ of removal) after 24 hours.

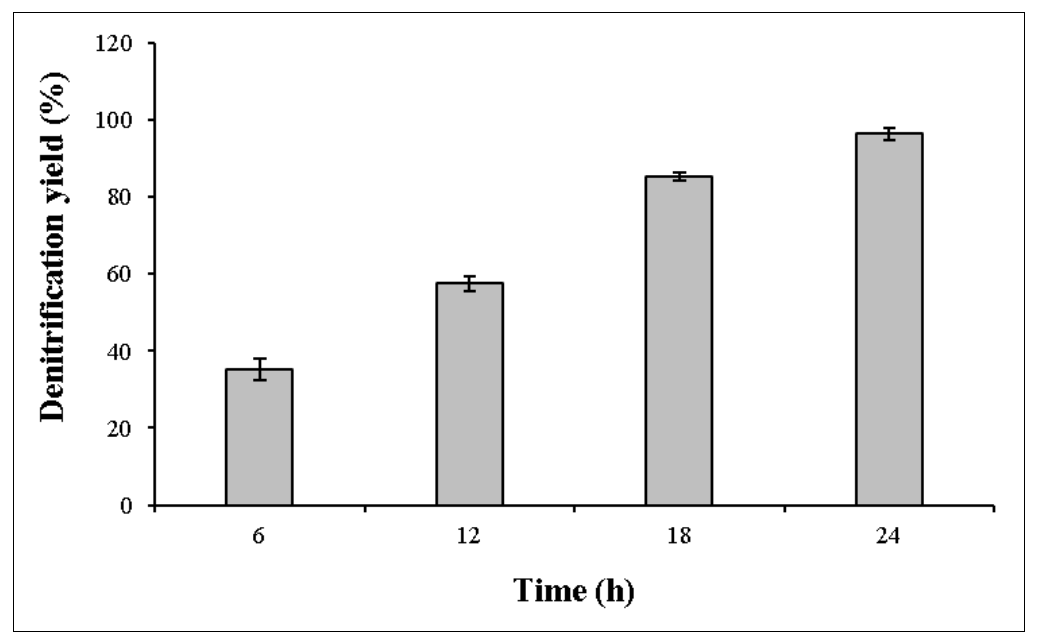

Figure 1. Denitrification efficiency versus experiment time. Initial $\mathrm{N}_{-} \mathrm{NO}_{3}{ }^{-}$concentration was $35 \mathrm{mg} \mathrm{L}^{-1}, 100 \mathrm{~mL}$ of MOso, $\mathrm{T}=30^{\circ} \mathrm{C}, \mathrm{pH}=7$

\subsection{Effect of Temperature on the Denitrification Process}

The temperature represents one of the most important factors for the success of denitrification. Here, Using MOso, optimal denitrification occurred between $25^{\circ} \mathrm{C}$ and $30{ }^{\circ} \mathrm{C}$ (Figure 2).

The rate of denitrification using MOso (Figure 2A) and MO IM (Figure 2B) increases with increasing temperature until the optimum value of $30^{\circ} \mathrm{C}$. Above $30{ }^{\circ} \mathrm{C}$, there was a decrease in efficiencies in the denitrification process.

At $40{ }^{\circ} \mathrm{C}$ and $50{ }^{\circ} \mathrm{C}$ and using MOso, denitrification processes were less efficient than at $25{ }^{\circ} \mathrm{C}$ and $30{ }^{\circ} \mathrm{C}$. These data corroborate with most of the reported studies that indicate an ideal denitrification temperature between $20{ }^{\circ} \mathrm{C}$ and $30{ }^{\circ} \mathrm{C}$ (Figure 2A) (Bucco et al., 2014; Liu et al., 2012).

At $25^{\circ} \mathrm{C}$ and $30{ }^{\circ} \mathrm{C}$, MOIM $(48 \mathrm{~h})$ and MOso $(24 \mathrm{~h})$ provided equivalent denitrification rates. However, in $24 \mathrm{~h}$, MOso provided larger denitrification rates (double) than MOIM, because MOIM activity is limited and reduced when compared to free cells in suspension MOso (Figure 2) (Bankston et al., 2020; Gan et al., 2019; Willaert, 2009). 

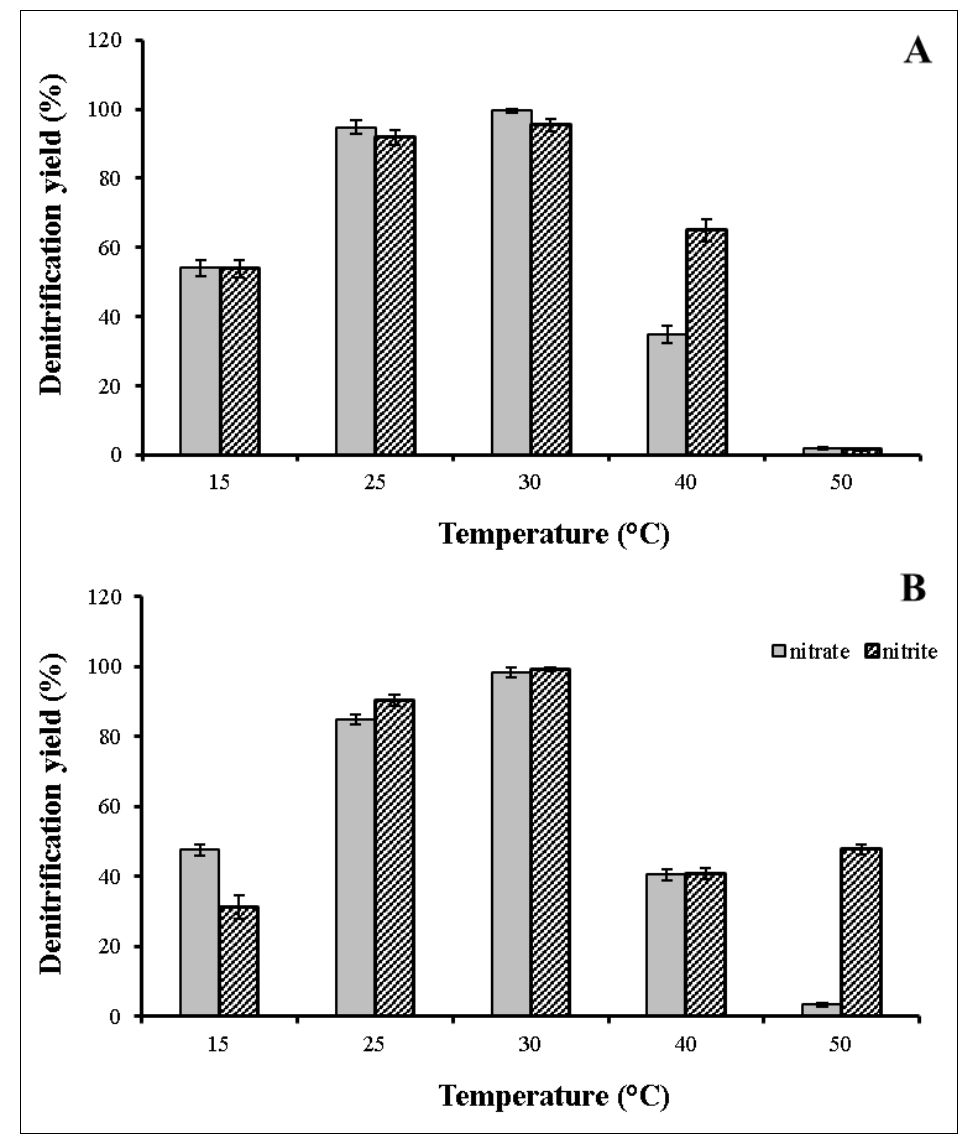

Figure 2. The efficiency of denitrification at different temperatures using MOIM and MOso as a source of denitrifying microorganisms in water contaminated with $35 \mathrm{mg} \mathrm{L}^{-1} \mathrm{~N}_{-} \mathrm{NO}_{3}^{-}$(A) MOso within 24 h, (B) MOIM within $48 \mathrm{~h}$

\subsection{Effect of $p H$ on the Denitrification Process}

Temperature and $\mathrm{pH}$ are crucial parameter in the biological denitrification process. Here, the best denitrification efficiencies were obtained at a pH 6-8 (Figure 3). Nancharaiah et al. (Nancharaiah et al., 2017) reported that denitrifying microorganisms tolerate $\mathrm{pH}$ between 6-8 and there was low denitrification out of this $\mathrm{pH}$ range.

The efficiency in nitrate removal using MOso increases with $\mathrm{pH}$ increase from 5 to 8 (Figure $3 \mathrm{~A})$. However, at $\mathrm{pH} 9$, nitrate and nitrite removal decrease, and best results were found at $\mathrm{pH} 7-8$. At $\mathrm{pH}$ 7-8 and using MOІм, nitrate removal was optimal at $\mathrm{pH} 7-8$. Nitrate removal efficiency increased from $59 \%$ to $94 \%$ when the $\mathrm{pH}$ of the medium raised from 5 to 8 (Figure 3B). However, when the $\mathrm{pH}$ goes from 8 to 9 , the nitrate removal efficiency drastically decreased from $94 \%$ to $40 \%$. This behavior agrees with other literature reports, which indicates that $\mathrm{pH}$ 6-8 is the optimum range for denitrifying microorganisms grow (Liu et al., 2012). 

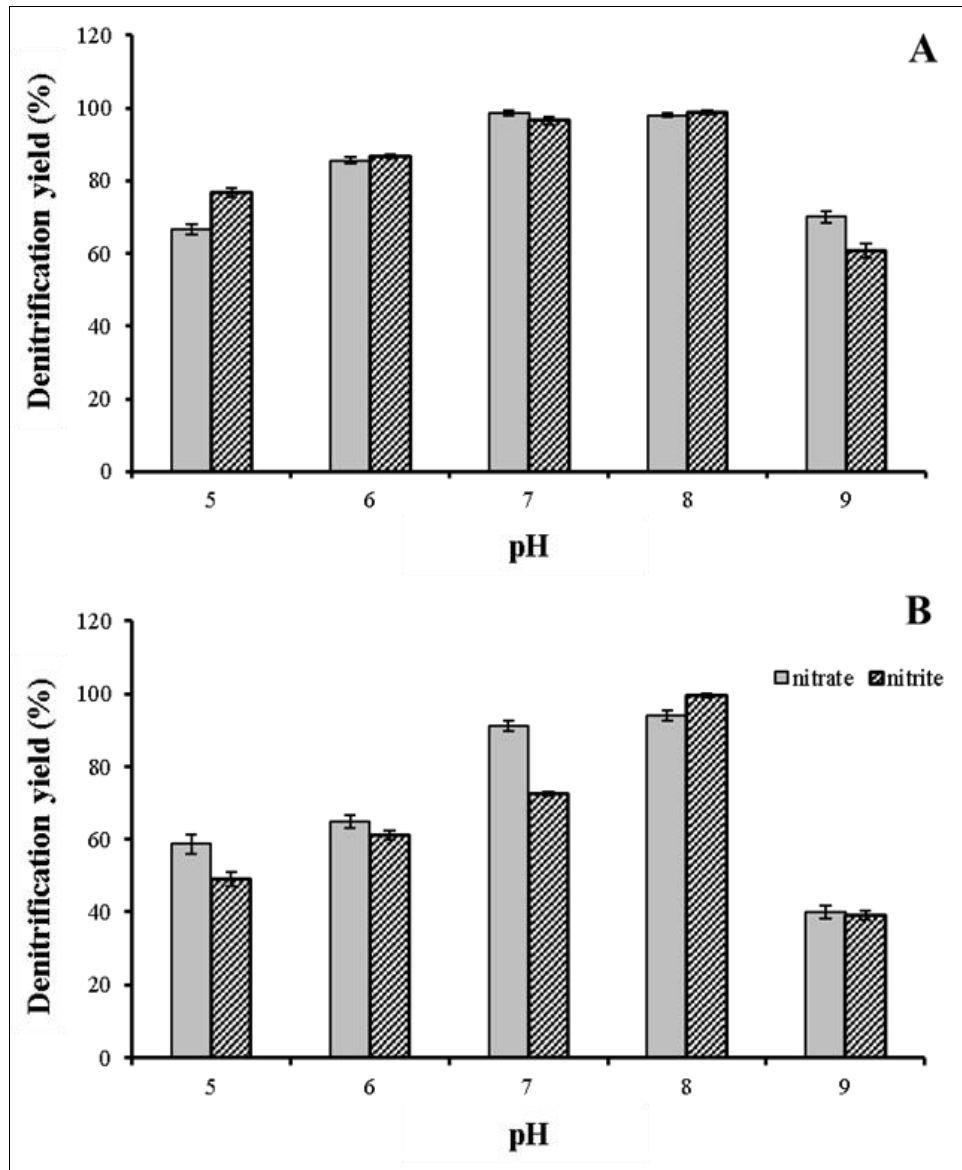

Figure 3. The efficiency of denitrification at different $\mathrm{pH}$ using MOІм and MOso as a source of denitrifying microorganisms in water contaminated with $35 \mathrm{mg} \mathrm{L}^{-1} \mathrm{~N}_{-\mathrm{NO}_{3}}^{-}$(A) $\mathrm{MO}_{\text {so }}$ within $24 \mathrm{~h}$ (B) MOIM within $48 \mathrm{~h}$

\subsection{Nitrate Concentration}

Figure 4 shows the efficiency of denitrification at different nitrate initial concentration using MOso (Figure 4A) and MO IM (Figure 4B) as a source of denitrifying microorganisms in water contaminated with nitrate and nitrite.

At 35 and $70 \mathrm{mg} \mathrm{L}^{-1} \mathrm{~N}_{-\mathrm{NO}_{3}}{ }^{-}$concentrations, the denitrification process using MOso is optimal, where nitrate and nitrite denitrification rates were equivalent, with an average close to $100 \%$ (Figure 4A). The denitrification process using MOІм is optimal, where nitrate denitrification rates were larger that nitrite denitrification rates, where nitrate denitrification efficiency were close to $100 \%$ and nitrite denitrification efficiency were close to $70 \%$ (Figure 4B).

At $140 \mathrm{mg} \mathrm{L}^{-1} \mathrm{~N}^{-\mathrm{NO}_{3}}{ }^{-}$concentration, nitrate removal using $\mathrm{MO}_{\text {so }}$ and $\mathrm{MO}_{\mathrm{IM}}$ was $52 \%$ and $59 \%$, respectively. Nitrite removal using $\mathrm{MO}_{\text {so }}$ and $\mathrm{MO}_{\text {IM }}$ were $87 \%$ and $60 \%$, respectively. At $280 \mathrm{mg} \mathrm{L}^{-1} \mathrm{~N}^{-\mathrm{NO}_{3}}{ }^{-}$concentrations, the nitrate removal efficiency using MOІм and MOso were $42 \%$ and 39\%, respectively, nitrite removal using MOso and MOІм were 45 and 80\%, respectively. It was possible to verify that nitrate concentration is a worth parameter for denitrifying bacteria growth rate and denitrifying efficiency was reduced in high nitrogen concentrations. 

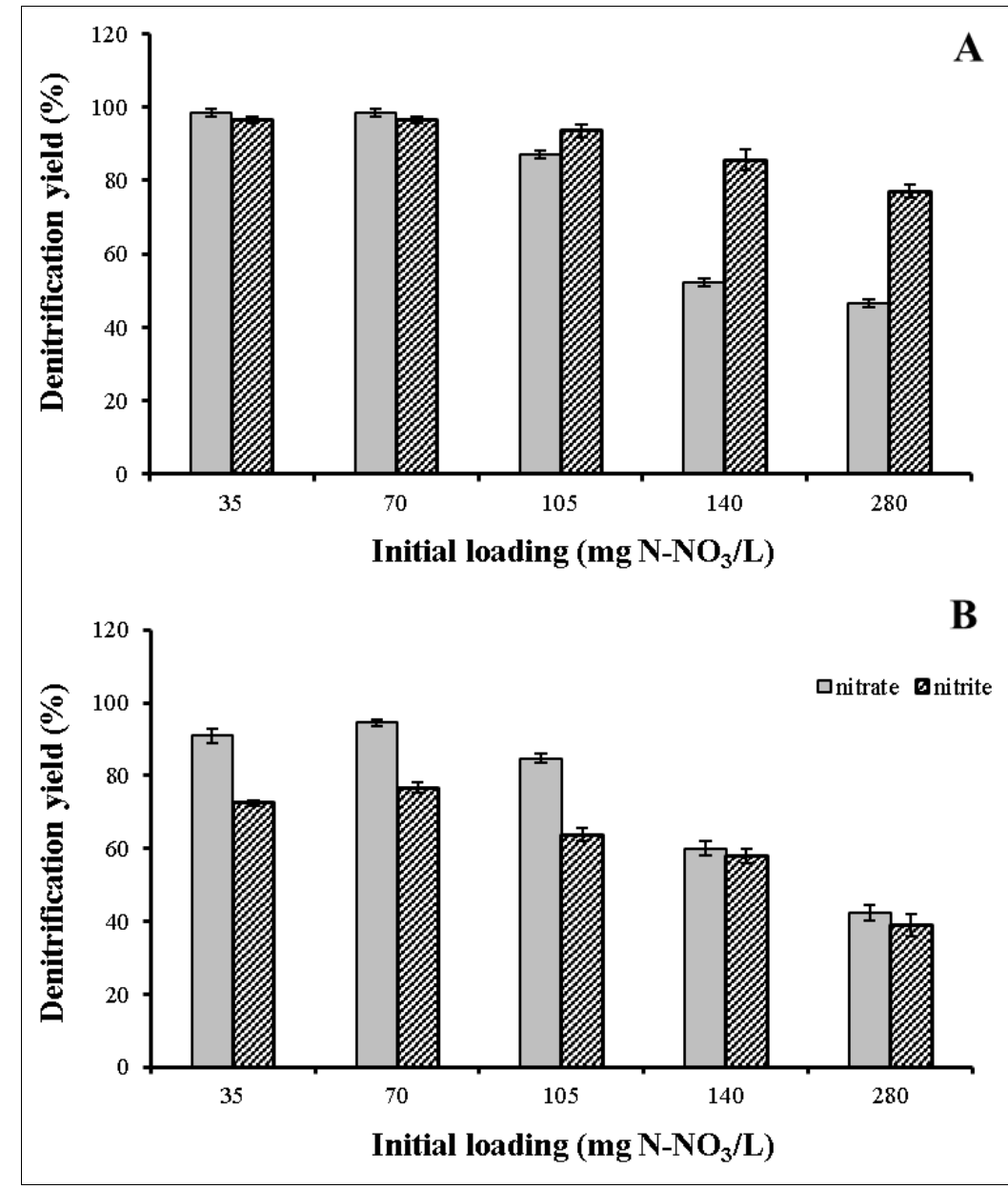

Figure 4. The efficiency of denitrification at different nitrate initial concentration using MO IM and MOso as a source of denitrifying microorganisms in water contaminated with $35-280 \mathrm{mg}$ $\mathrm{L}^{-1} \mathrm{~N}_{-\mathrm{NO}_{3}}^{-}$(A) MOso within $24 \mathrm{~h}$ (B) MOIM within $48 \mathrm{~h}$

\subsection{Carbon Sources}

In water denitrification process, organics compounds, which are electron donors, contribute to the process. As facultative heterotrophic bacteria, the denitrification process requires organic substrates as electron donors to effectively support the reduction of nitrate to $\mathrm{N}_{2}$. Therefore, the concentration of bioavailable organic substrates as carbon sources is a mandatory parameter for the process (Wei et al., 2017). Methanol, ethanol, and sodium acetate are carbon sources. Methanol is toxic, ethanol and sodium acetate have been used as an organic carbon source since these compounds have low toxicity than methanol (Tian \& Yu, 2020).

Denitrification efficiency using ethanol and sodium acetate in different stoichiometry ratios were shown in Figure 5 and Figure 6, respectively. Considerable denitrification was identified even without addition of an external carbon source. Thus, we identified that denitrifying microorganisms grow and denitrify using rice husk biomass as carbon source.

The efficiency of nitrate and nitrite removal using MOso and ethanol with 1:1, 1:2, 1:3 and 1:4 $\mathrm{C} / \mathrm{N}$ ratios were equivalent, with removal above 97\% (Figure 5A). The efficiency of 


\section{Macrothink}

Journal of Agricultural Studies

ISSN 2166-0379

2020, Vol. 8, No. 4

nitrate removal using $\mathrm{MO}_{\mathrm{IM}}$ and ethanol with $1: 1,1: 2,1: 3$ and $1: 4 \mathrm{C} / \mathrm{N}$ ratios were equivalent, showing an average of $80 \%$ of removal for the investigated $\mathrm{C} / \mathrm{N}$ ratio, nitrite removal was close to $100 \%$ (Figure 5B).

Aqueous solutions containing $\mathrm{C} / \mathrm{N}$ ratio of 3 5 support the metabolism of heterotrophic microorganisms (He et al., 2016). When the $\mathrm{C} / \mathrm{N}$ ratio is too low to provide sufficient electron donors to the bacteria, the denitrification process requires biodegradable organic matters as external carbon sources (Wei et al., 2017).

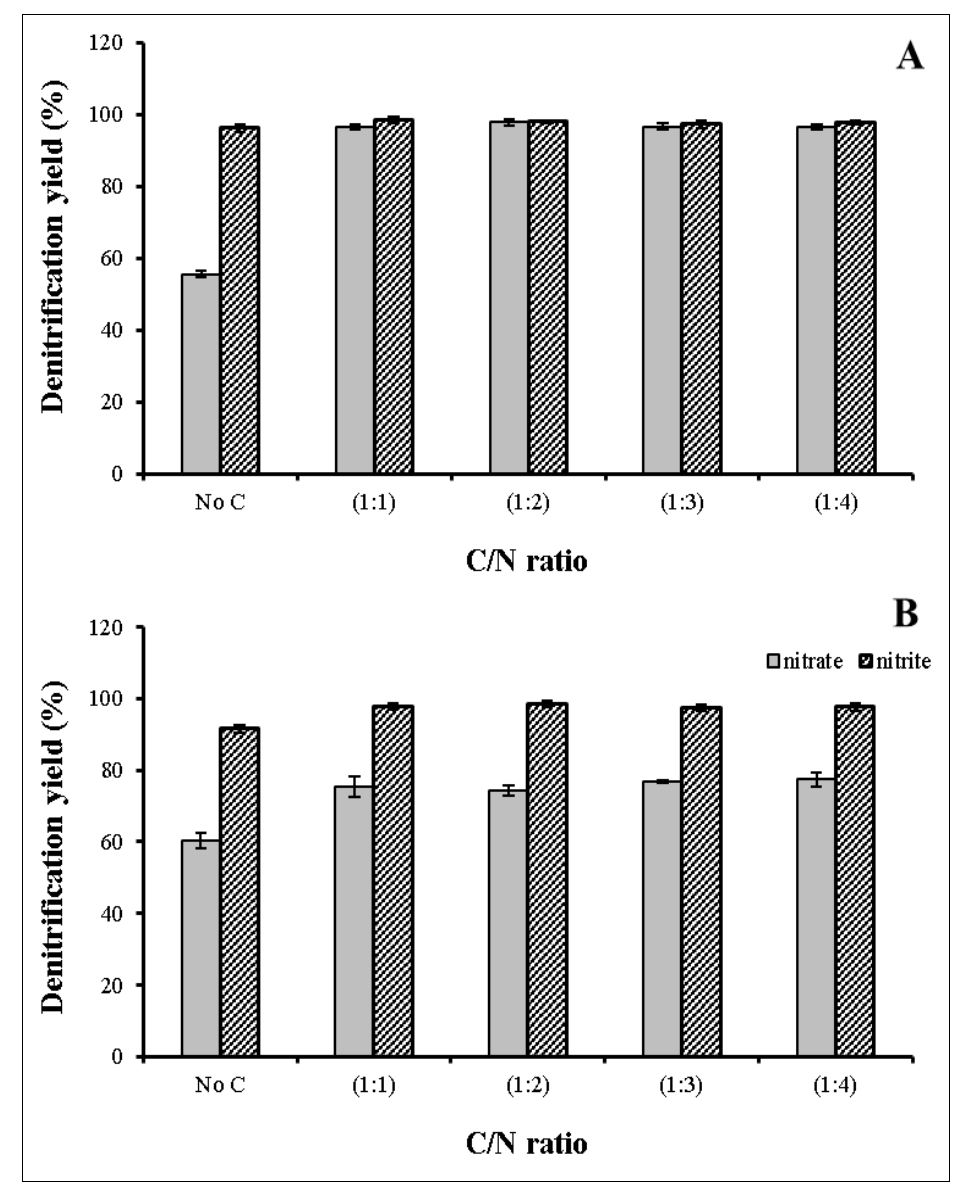

Figure 5. Efficiency of denitrification using ethanol in different stoichiometric ratios. (A) MOso within $24 \mathrm{~h}$ (B) MOIM within $48 \mathrm{~h}$

When denitrification process was carried out using sodium acetate as carbon source and MOso (Figure 6A), in all $\mathrm{C} / \mathrm{N}$ ratios, nitrite and nitrate removal was close to $100 \%$, without a carbon source, nitrate removal was just $55 \%$. When denitrification process was carried out using sodium acetate as carbon source and МО Ім (Figure 6B), in all $\mathrm{C} / \mathrm{N}$ ratios, nitrate removal was close to $77 \%$ and nitrite removal was close to $96 \%$, without a carbon source, nitrate removal was just $55 \%$.

Without a carbon source, MOso and МOІм provided equivalent nitrate and nitrite removal. In addition, the efficiency of nitrate and nitrite removal using MO IM was larger than those obtained using MOso (Figure 6). 

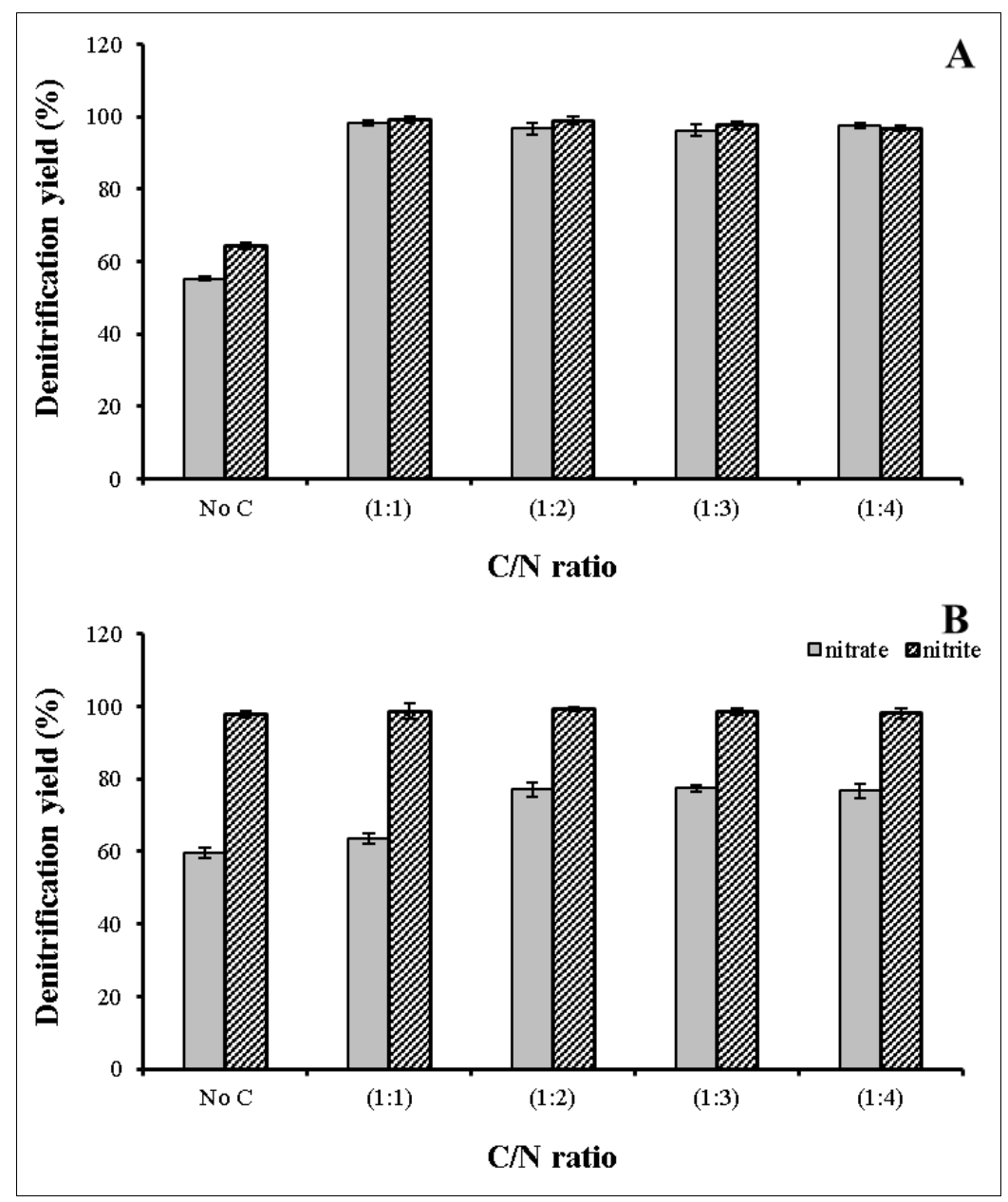

Figure 6. Efficiency of denitrification using sodium acetate in different stoichiometric ratios. (A) MOso within $24 \mathrm{~h} \mathrm{(B)} \mathrm{MOIM} \mathrm{within} 48 \mathrm{~h}$

In scientific literature other external carbon sources are being studied for denitrification purposes. $\mathrm{Hu}$ et al. (Hu et al., 2017) studied denitrification efficiency in soil using sawdust. They claimed that the denitrification efficiency of sawdust was low because of its poor carbon availability. Thus, they treated sawdust with lime and peracetic acid to enhance the carbon availability. As a result, they increase denitrification efficiency and it was mainly attributed to the removal of lignin from the biomass.

\subsection{Operational Robustness Assessment}

The first cycle for the generation of microorganisms with the crude extract required $72 \mathrm{~h}$ for the complete removal of nitrate. On the other hand, subsequent cycles required only $24 \mathrm{~h}$.

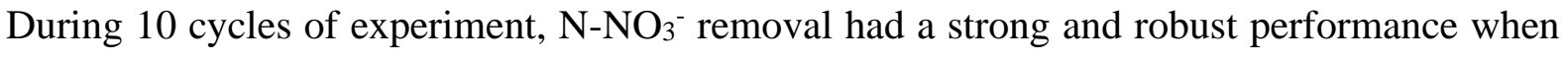
fed with the same amount of substrate $(\mathrm{C} / \mathrm{N})$, indicating the possibility of biomass reuse in several cycles of denitrification (Table 1 ). 
Table 1. Denitrification for different subtract percentages, $\% .35 \mathrm{mg}$ de $\mathrm{N}-\mathrm{NO}_{3}{ }^{-1} \mathrm{~L}^{-1}$, each cycle 24 hours and $\mathrm{T}=30^{\circ} \mathrm{C}$

\begin{tabular}{cllllll}
\hline \multicolumn{7}{c}{ Concentrations of the crude extract } \\
\hline cycles & $100 \%$ & $50 \%$ & $40 \%$ & $30 \%$ & $20 \%$ & $10 \%$ \\
1 & 100 & 100 & 100 & 100 & 100 & 79 \\
2 & 100 & 100 & 100 & 100 & 100 & 78 \\
3 & 100 & 99 & 100 & 99 & 100 & 80 \\
4 & 99 & 99 & 99 & 99 & 98 & 80 \\
5 & 99 & 99 & 99 & 100 & 98 & 82 \\
6 & 98 & 99 & 99 & 99 & 99 & 82 \\
7 & 100 & 98 & 99 & 99 & 98 & 78 \\
8 & 99 & 98 & 98 & 98 & 98 & 79 \\
9 & 97 & 98 & 99 & 98 & 97 & 81 \\
10 & 98 & 98 & 98 & 99 & 98 & 79 \\
\hline
\end{tabular}

After 10 cycles, concentrations of $20 \%$ a $100 \%$ of the crude extract provided nitrate removal close to $100 \%$. In this crude extract range, according any-away ANOVA, nitrate removals were equivalent $(\mathrm{p} \leq 0.05)$. However, using $10 \%$ of the extract, nitrate removal efficiency decreased to $80 \%$.

The microorganisms produced from the rice husks have great potential to be employed on nitrogen removal. The denitrifying process presented was robust and it presented nitrate removal close to $100 \%$ during 10 cycles. The only concern found, after 10 cycles, was the appearance of a yellowish color of the aqueous solution, indicating accumulation of chromophores along the biological treatment.

\section{Conclusion}

The principle of denitrification in this research was biological denitrification. The denitrification of microorganisms in MOso was always higher than in $\mathrm{MO}_{\mathrm{IM}}$ under different conditions because the microorganisms are dispersed in the solution which improves the contact area between the microorganisms and nitrogen compounds.

Biological denitrification of contaminated water using wild type microorganisms from rice husk were an effective and promising approach. This immobilized and suspended MO had optima denitrifying efficiency at $25-30{ }^{\circ} \mathrm{C}$ and at $\mathrm{pH}$ 6-8.

The average denitrification efficiency using MOso was larger than it was obtained using MOІм. Moreover, MOІм approach was more $\mathrm{pH}$ sensitive than the MOso approach. Ethanol and sodium acetate were good carbon sources for MO denitrifying for both approaches. The efficiency of nitrate and nitrite removal using MOso and ethanol with 1:1, 1:2, 1:3 and 1:4 $\mathrm{C} / \mathrm{N}$ ratios were equivalents, with removal above $97 \%$. Using sodium acetate and MOso, the denitrification efficiencies were close to $100 \%$ for all $\mathrm{C} / \mathrm{N}$ ratios, without any carbon source, nitrate removal was 55\%. Similar results were obtained using MOso.

We conclude that the presented process was efficient and robust since nitrate and nitrate were removed with efficiencies close to $100 \%$ in 10 cycles. 


\section{References}

Abu Hasan, H., Muhammad, M. H., \& Ismail, N. I. (2020). A review of biological drinking water treatment technologies for contaminants removal from polluted water resources. Journal of Water Process Engineering, 33, 101035. Elsevier Ltd. https://doi.org/10.1016/j.jwpe.2019.101035

APHA, (2012). Standard methods for the examination of water and wastewater, 22nd edition edited by E. W. Rice, R. B. Baird, A. D. Eaton and L. S. Clesceri. American Public Health Association (APHA), American Water Works Association (AWWA) and Water Environment Federation (WEF), Washington, D.C., USA. file:///C:/Users/mhlsi/Downloads/standardmethodsfortheexaminationofwaterandwastewater1 000-3000.pdf

Bankston, E., Wang, Q., \& Higgins, B. T. (2020). Algae support populations of heterotrophic, nitrifying, and phosphate-accumulating bacteria in the treatment of poultry litter anaerobic digestate. Chemical Engineering Journal, 125550. https://doi.org/10.1016/j.cej.2020.125550

Bucco, S., Padoin, N., Netto, W. S., \& Soares, H. M. (2014). Drinking water decontamination by biological denitrification using fresh bamboo as inoculum source. Bioprocess and Biosystems Engineering, 37(10), 2009-2017. https://doi.org/10.1007/s00449-014-1176-7

Chen, J., Xu, Y., Li, Y., Liao, J., Ling, J., Li, J., \& Xie, G. (2019). Effective removal of nitrate by denitrification re-enforced with a two-stage anoxic/oxic (A/O) process from a digested piggery wastewater with a low C/N ratio. Journal of Environmental Management, 240, 19-26. https://doi.org/10.1016/j.jenvman.2019.03.091

Chuah, T. G., Jumasiah, A., Azni, I., Katayon, S., \& Thomas Choong, S. Y. (2005). Rice husk as a potentially low-cost biosorbent for heavy metal and dye removal: An overview. Desalination, 175(3), 305-316. https://doi.org/10.1016/j.desal.2004.10.014

Della, V. P., Kühn, I., \& Hotza, D. (2001). Characterization of rice husk ash for use as raw material in the manufacture of silica refractory. Química Nova, 24, 778-78. https://doi.org/10.1590/S0100-40422001000600013

Di Capua, F., Pirozzi, F., Lens, P. N. L., \& Esposito, G. (2019). Electron donors for autotrophic denitrification. Chemical Engineering Journal, 362, 922-937. Elsevier B.V. https://doi.org/10.1016/j.cej.2019.01.069

Fan, A. M., \& Steinberg, V. E. (1996). Health implications of nitrate and nitrite in drinking water: An update on methemoglobinemia occurrence and reproductive and developmental toxicity. Regulatory Toxicology and Pharmacology, 23(1I), 35-43. https://doi.org/10.1006/rtph.1996.0006

Gan, Y., Zhao, Q., \& Ye, Z. (2019). Denitrification performance and microbial diversity of immobilized bacterial consortium treating nitrate micro-polluted water. Bioresource Technology, 281, 351-358. https://doi.org/10.1016/j.biortech.2019.02.111 
Garcia-Segura, S., Lanzarini-Lopes, M., Hristovski, K., \& Westerhoff, P. (2018). Electrocatalytic reduction of nitrate: Fundamentals to full-scale water treatment applications. Applied Catalysis B: Environmental, 236, 546-568. Elsevier B.V. https://doi.org/10.1016/j.apcatb.2018.05.041

He, Y., Wang, Y., \& Song, X. (2016). High-effective denitrification of low C/N wastewater by combined constructed wetland and biofilm-electrode reactor (CW-BER). Bioresource Technology, 203, 245-251. https://doi.org/10.1016/j.biortech.2015.12.060

He, Q., Zhang, D., Main, K., Feng, C., \& Ergas, S. J. (2018). Biological denitrification in marine aquaculture systems: A multiple electron donor microcosm study. Bioresource Technology, 263, 340-349. https://doi.org/10.1016/j.biortech.2018.05.018

Hou, T., Chen, N., Tong, S., Li, B., He, Q., \& Feng, C. (2019). Enhancement of rice bran as carbon and microbial sources on the nitrate removal from groundwater. Biochemical Engineering Journal, 148, 185-194. https://doi.org/10.1016/j.bej.2018.07.010

Hu, R., Zheng, X., Xin, J., Sun, Z., \& Zheng, T. (2017). Selective enhancement and verification of woody biomass digestibility as a denitrification carbon source. Bioresource Technology, 244, 313-319. https://doi.org/10.1016/j.biortech.2017.07.162

João, J. J., Locks, L., Vieira, J. L., \& Lucia, E. A. (2020). Rice husks as a microbial source $\begin{array}{lll}\text { for } \quad \text { wastewater } & \text { 24(5), }\end{array}$ https://doi.org/10.1590/1807-1929/agriambi.v24n5p343-347

Júnior, H. M., Silva, J. da, Arenzon, A., Portela, C. S., Ferreira, I. C. F. de S., \& Henriques, J. A. P. (2007). Evaluation of genotoxicity and toxicity of water and sediment samples from a Brazilian stream influenced by tannery industries. Chemosphere, 67(6), 1211-1217. https://doi.org/10.1016/j.chemosphere.2006.10.048

Liu, Y., Gan, L., Chen, Z., Megharaj, M., \& Naidu, R. (2012). Removal of nitrate using Paracoccus sp. YF1 immobilized on bamboo carbon. Journal of Hazardous Materials, 229-230, 419-425. https://doi.org/10.1016/j.jhazmat.2012.06.029

Liu, X., Huang, M., Bao, S., Tang, W., \& Fang, T. (2020). Nitrate removal from low carbon-to-nitrogen ratio wastewater by combining iron-based chemical reduction and autotrophic denitrification. Bioresource Technology, 301, 122731. https://doi.org/10.1016/j.biortech.2019.122731

Maheshwari, D. K., Dheeman, S., \& Agarwal, M. (2014). Decomposition of Organic Materials into High Value Compost for Sustainable Crop Productivity (pp. 245-267). Springer, Cham. https://doi.org/10.1007/978-3-319-08004-8_12

Nancharaiah, Y. V., Krishna Mohan, T. V., Satya Sai, P. M., \& Venugopalan, V. P. (2017). Denitrification of high strength nitrate bearing acidic waters in granular sludge sequencing batch reactors. International Biodeterioration and Biodegradation, 119, 28-36. https://doi.org/10.1016/j.ibiod.2016.10.057

Pan, J., Gao, B., Song, W., Xu, X., \& Yue, Q. (2020). Modified biogas residues as an 
eco-friendly and easily-recoverable biosorbent for nitrate and phosphate removals from surface water. Journal of Hazardous Materials, 382, 121073. https://doi.org/10.1016/j.jhazmat.2019.121073

Shamsollahi, Z., \& Partovinia, A. (2019). Recent advances on pollutants removal by rice husk as a bio-based adsorbent: A critical review. Journal of Environmental Management, 246, 314-323. Academic Press. https://doi.org/10.1016/j.jenvman.2019.05.145

Tian, T., \& Yu, H. Q. (2020). Denitrification with non-organic electron donor for treating low C/N ratio wastewaters. Bioresource Technology, 299, 122686. Elsevier Ltd. https://doi.org/10.1016/j.biortech.2019.122686

Wan, R., Zheng, X., Chen, Y., \& Wang, H. (2015). Using cassava distiller's dried grains as carbon and microbe sources to enhance denitrification of nitrate-contaminated groundwater.

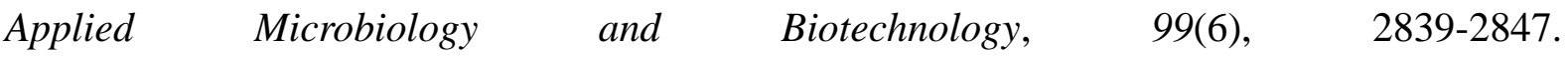
https://doi.org/10.1007/s00253-014-6155-z

Wei, Y., Dai, J., Mackey, H. R., \& Chen, G. H. (2017). The feasibility study of autotrophic denitrification with iron sludge produced for sulfide control. Water Research, 122, 226-233. https://doi.org/10.1016/j.watres.2017.05.073

Willaert, R. (2009). Cell Immobilization: Engineering Aspects. Encyclopedia of Industrial Biotechnology, 1-29. John Wiley \& Sons, Inc. https://doi.org/10.1002/9780470054581.eib200

Zhang, Y., Wang, X. C., Cheng, Z., Li, Y., \& Tang, J. (2016). Effect of fermentation liquid from food waste as a carbon source for enhancing denitrification in wastewater treatment. Chemosphere, 144, 689-696. https://doi.org/10.1016/j.chemosphere.2015.09.036

\section{Copyright Disclaimer}

Copyright for this article is retained by the author(s), with first publication rights granted to the journal.

This is an open-access article distributed under the terms and conditions of the Creative Commons Attribution license (http://creativecommons.org/licenses/by/4.0/). 